\title{
INFLUENCE OF HYPODYNAMY ON THE BONE MARROW STROMAL CELLS (CFU-f) IN JAPANESE QUAIL
}

\author{
A.VACEK ${ }^{1}, \mathrm{~K} . \mathrm{BODA}^{2}, \mathrm{~V} . \mathrm{SABO}^{3}$ \\ ${ }^{1}$ Institute of Biophysics, Czech Academy of Sciences, Brno \\ Czech Republic, ${ }^{3}$ Institute of Experimental Veterinary Medicine, Slovak Academy of Sciences, 900 28Ivanka \\ pri Dunaji, Slovak Republic
}

Received June 5, 1995

Accepted June 6, 1996

\begin{abstract}
V a c e K A., K. B od a, V.S a bo:Influence of Hypodynamy on the Bone Marrow Stromal Cells (CFU-f) in Japanese Quail. Acta vet. Brno 1996, 65: 83-85.

In Japanese quail the effect of a 90 day immobilization on the pool of bone marrow stromal cells (CFU-f) was studied. CFU-f were determined in femur and tibia by a tissue culture method at different times of immobilization. A linear decrease in the number of CFU-f in both tissues was found during 60 days of immobilization with a subsequent adaptation at the low level of the pool of CFU-f. The results indicate a profound effect of hypodynamy on the bone marrow microenvironment.
\end{abstract}

Bone marrow, stroma, cells (CFU-f), hypodynamy

The aim of this presentation is to contribute to the expanding research of the biological effects of hypodynamy as a model of the influence of the space effect of reduced gravity. The space flight accompanied by microgravity and following overload represents a complex factors exerting possible effects on the organism and produce changes in the body at the level of cells, tissues and regulatory systems (G a z e n k o et al. 1975). One of the manifestations of the effect of space flight factors on a living organism is a decrease in the number of the stromal cells in the bone marrow of rats flown on board of the Cosmos biosattelite (V a c e k et al. 1990), as well as during suspension hypodynamy (V a c e k et al. 1991). This can be a result of the unloading on the musculo-skeletal system in microgravity that causes bone growth inhibition and osteoporosis (Kaplansky et al. 1987,1991). There are no data on the influence of hypodynamy on the bone marrow stromal cells in the Japanese quail, and the presented experiment studied the effect of various lenghts of hypodynamy on the the bone marrow cells of Japanese quail.

\section{Materials and Methods}

Five groups of Japanese quail were used in the experiments. Description of the method of hypodynamy is given by Juráni et al. (1983).

Stromal cells in the bone marrow ( CFU-f) were determined in the femur and tibia of Japanese quail using a cultivation in vitro by the method of Friedenstein (1976) in our modification ( V a c e k et al. 1990). Bone marrow nucleated cells were cultivated in the medium alpha-MEM in Petri dishes (Koh-i-noor, Hardtmuth, Dalečin, Czech Republic) at $37^{\circ} \mathrm{C}$ in a humidified atmosphere of $5 \% \mathrm{CO}_{2}$ in air. Per experimental group bone marrow cells from 7 femurs and 12 tibias were used.

\section{Results and Discussion}

Results presented in Fig. 1 show that in both femur and tibia hypodynamy induced changes in the number of stromal cells with a gradual decrease of their numbers. Lowest values were observed at the interval of 60 days hypodynamy. In a 90 day of hypodynamy a small and non-significant elevation may indicate an adaptation to hypokinesia. However, the numbers 


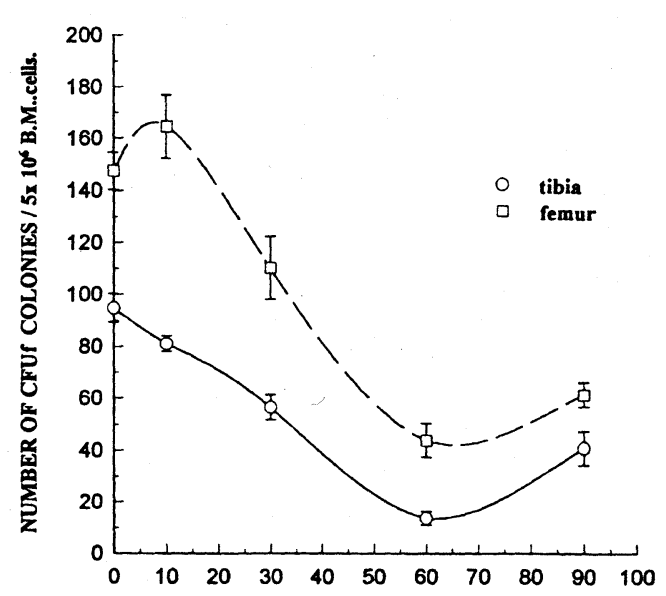

of CFU-f in the intervals of 30,60 and 90 days of hypodynamy were significantly $(\mathrm{P}<0.01)$ lower than those in the control group.

This observation extends our knowledge on the effect of hypodynamy on the stromal cells of the bone marrow that are forming the haemopoietic microenvironment ( $\mathrm{O}$ we $\mathrm{n}$ et al. 1987). A close relationship between cell elements of the haemopoietic cell populations and osteoblast progenitors (Hagenaars et al. 1989) was shown. Bone marrow fibroblasts produce stimulatory factors that activate proliferation of bone and haemopoietic progenitors (B lackburn and Patt 1977). Fibroblastogenic growth factors are not only mitogenic agents but they can also influence the metabolism of the bone cells, including collagen synthesis ( $\mathrm{McCarthy}$ et al. 1989). Therefore the decrease in the number of stromal cells in our Japanese quail may be related to the influence of hypodynamy on the metabolism of the bone. To analyse the mechanisms of these influences, however, further experiments are needed.

\section{Vliv hypodynamie na stromální bunky (CFU-f) kostní dřeně japonské křepelky}

U japonských křepelek imobilizovaných po 90 dnů, byl studován vliv hypodynamie na progenitory stromálních buněk kostní dřeně (CFU-f). Počty CFU-f byly sledovány in vitro ve tkáňových kulturách suspenze kostní dřeně femuru a tibie, odebraných $\mathrm{v}$ různou dobu trvání hypodynamie. Po 60 dnech imobilizace došlo $\mathrm{k}$ lineárnímu poklesu počtu CFU-f v obou tkáních s následnou adaptací na velikost poolu CFU-f. Výsledky ukazují na velký vliv hypodynamie na mikroprostředí kostní dřeně.

\section{Влияние иммобилизации на стромальные клөтки (CFU-f) костного мозга японской перепелки}

В экспериментах исследовалось влияние 90-дневной иммобилизации на пул стромальных клеток костного мозга (CFU,). Прогениторы стромальных клеток определяли в тканевых культурах звеси костного мозга бедра и голени перепелки в разные сроки ее иммобилизации. Найдено, что на протяжении 60 дней иммобилизации линеарно падает содержание CFU-f в обеих тканях с последующей адаптацией на низком уровне. Результаты показывают, что гипокинезия существенно влияет на микросреду костного мозга.

\section{References}

BLACKBURN, M. J., PATT, H. M. 1976: Brit. J. Haematol. 37:337-344

FRIEDENSTEIN, A. J. 1976:Int. Rev. Cytol. 47:327-355

GAZENKO, O. G., ADAMOVICH, B. A., ILIIN, E. A. 1975: Vestnik Akad. Nauk 9:62-65

HAGENAARS, C. E., van der KRAAN, A. A. M., KAWILARANG-de HAAS, E. M., VISSER, J. W. M., NIJWEIDE, P. J. 1989: Bone and Mineral 6:179-189 
JURANI, M., VÝBOH, P.,LAMOŠOVÁ, D., BAROŠKOVÁ, Ž., SOMOGYIOVÁ, E., BOĎA, K.,GAŽO, M. 1983: The Physiologist 26:145-148

KAPLANSKY, A. S., DURNOVA, G. N., SAKHAROVA, E. F., ILYINA-KAKUEVA, E. I. 1987: Kosm. Biol. 21(5):25-31

KAPLANSKY, A. S., DURNOVA, G. N., BUKOVSKAYA, T. E., VOROTNIKOVA, E. V. 1991: The Physiologist 34/1/S:196-199

MCCARTHY, T. I., CENTRELLA, M., CANALIS, E. 1989: Endocrinology 125:2118-2126

OWEN, M. E., CAVE, J., JOYNER, C. J.: J. Cell. Sci. 87:731-738

VACEK, A., BUEVEROVA, E. I., MICHURINA, T. V., ROTKOVSKÁ, D., SEROVA, L. V. BARTONIĆKOVÁ, A. 1990: Folia Biol. (Praha) 36:194-1970

VACEK, A., SEROVA, L. V., BARTONIČKOVA, A., ROTKOVSKA, D., KAUTSKA, J., MICHURINA,T.V. 1991:In: Current Trends in Cosmic Biology and Medicine, Ed. Boda, K., Institute of Animal Biochemistry and Genetics, SAS,Ivanka pri Dunaji, pp. 27-35 